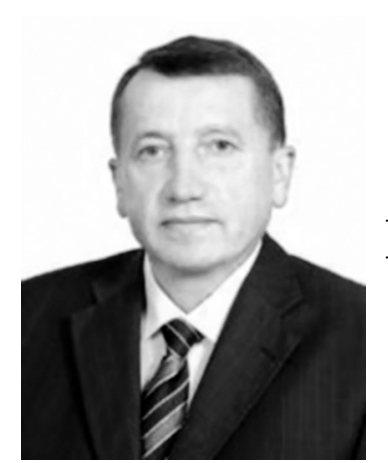

\title{
МОНІТОРИНГ БАНКІВСЬКИХ РАХУНКІВ ЯК НЕГЛАСНА СЛІДЧА ДІЯ: ВІТЧИЗНЯНИЙ ТА ІНОЗЕМНИЙ ДОСВІД ПРОЦЕСУАЛЬНОГО ЗАБЕЗПЕЧЕННЯ
} \begin{abstract}
професор кафедри кримінального права і процесу Навчально-наукового Інституту права, психології та інноваційної освіти Національного університету «Львівська політехніка», заслужений юрист України.
\end{abstract}

ОРТИНСЬКИЙ Володимир Львович - доктор юридичних наук, професор,

DOI:10.32782/EP.2020.2.12

Статья посвящена прочессуальной правовой платборме мониторинга банковских счетов, как негласное следственное (розвикное) действие. Научнъие исследования этого института полезнъ как с позищий соблюдения конституционньхх прав граждан в бинансовоправовых отношениях, так и для следственной и судебной практики.

B статъе рассмотрено понятие и содержание инбормации, которую можно определить как банковскую тайну, вълсняется процуедура проведения мониторинга банковских счетов, определенъ основнвие требования процессуального сопровождения, сроки проведения, типичные следственнве ситуачии. Проанализирован опьт отдельных иностранных государств в сбере предотврашения и противодействия легализачии (отмьлванию) доходов, полученнъхх преступнъм путем и бинансированию терроризма

Ключевъе слова: негласное следственное (розвискное) действие, мониторинг банковских счетов, процессуальное сопровождение, бинансово-правовъие отношения, следственная техника, банковская тайна.

\section{Вступ}

Для більшості європейських держав заходи, які є подібними до вітчизняних негласних слідчих (розшукових) дій у розслідуванні злочинів, вже давно стали звичним явищем. Перевірка законності проведення таких заходів неодноразово була предметом розгляду Європейського суду з прав людини (далі - ЄСП $)$. Судова практика з цього питання свідчить про те, що право держави на таємне втручання у права громадян визнається ЄСП д допустимим лише за наявності відповідних умов, однією з яких є можливість такого втручання способом, визначеним Законом. Така вимога покликана зробити вказане втручання держави передбаченим для громадян, істотно ускладнювати зловживання владних інституцій і надати особам, права яких були обмежені та порушені, ефективні засоби контролю і правового захисту. Так, за офіційними даними, у низці держав Европи (Великобританія, Німеччина, Франція, Нідерланди, Данія, Швейцарія тощо) уже наприкінці 80-x - початку 90 -х років XIX сторіччя у кримінальному процесуальному законодавстві були передбачені нові, як їх називали, «спеціальні» («особливі)» слідчі дiï.

Різноманітні теоретичні і практичні проблеми негласного отримання інформації відображені у наукових працях як відомих вітчизняних, так і закордонних науковців, як-от: О.М. Бандурка, Б.І. Бараненко, Р.І. Благута, Е.О.Дідоренко, О.М. Дроздов, I.I. Когутич, А.М. Аобойко, Д.Й. Никифорчук, В.Т. Нор, М.А. Погорецький, В.М. Тертишник, А.Д. Удалова, В.Г. Уваров, Р.М, Шехавцов, М.С. Шумило та ін.

В умовах суттєвого оновлення вітчизняного кримінального процесу виникає потреба дослідження загальнотеоретичного та нормативно-правового аналізу про- 


\section{Кримінальне право, кримінальний процес та криміналістика}

цесуальних аспектів моніторингу банківських рахунків в Україні та окремих зарубіжних держав.

\section{Постановка проблеми}

Відповідно до ч. 66 ст. 1 Закону України «Про запобігання та протидію легалізації (відмиванню) доходів, одержаних злочинним шляхом, фінансуванню тероризму та фінансуванню розповсюдження зброї масового знищення» фінансовий моніторинг - сукупність заходів, що вживаються суб'єктами фінансового моніторингу у сфері запобігання та протидії, що включають проведення державного фінансового моніторингу та первинного фінансового моніторингу [1].

Моніторинг банківських рахунків як НСРД була запроваджена у вітчизняне законодавство задля забезпечення міжнародних зобов'язань України в частині боротьби 3 відмиванням коштів та фінансування тероризму, а також надання можливості НАБУ ефективно боротися 3 корупційними правопорушеннями посадовців високого рангу.

Міжурядовим органом, метою роботи якого $E$ розвиток i впровадження на міжнародному рівні заходів і стандартів 3 боротьби щодо відмивання грошей, 6 ФАТФ (Financial Action Task Force on Money Laundering). Функції ФАТФ полягають у відслідковуванні процесів імплементації таких заходів, вивчає способи і техніку відмивання грошей, розробляє превентивні та запобіжні заходи, сприяе загальносвітовій імплементації стандартів боротьби 3 відмиванням грошей. ФАТФ плідно співпрацює з багатьма міжнародними організаціями, діяльність яких спрямована на протидію відмиванню «брудних» грошей. Ця організація була заснована в липні 1989 року з ініціативи президента Франції і Європейської комісії під час Паризької зустрічі на вищому рівні сімома провідними державами: Францією, США, Канадою, Японією, Німеччиною, Великобританією та Італією.

Рекомендації ФАТФ передбачають, що держави повинні забезпечити, щоб їх компетентні органи при проведенні роз- слідувань мали можливість використовувати широкий спектр слідчих технік, які можуть бути застосовані до розслідування відмивання коштів, пов'язаних предикатних злочинів та фінансування тероризму. Такі слідчі техніки включають: таємні операції, перехоплення зв’язку, організація доступу до комп'ютерних систем та контрольовані поставки. Крім того, держави повинні мати ефективні механізми для вчасного встановлення того, чи ведуть та контролюють фізичні або юридичні особи рахунки [2].

В Україні таким органом державної влади, який уповноважений здійснювати моніторинг, є Державна служба фінансового моніторингу. Держфінмоніторингом, як підрозділом фінансової розвідки України, вживаються посилені заходи практичного характеру щодо протидії легалізації (відмиванню) доходів, одержаних злочинним шляхом, фінансуванню тероризму та фінансуванню розповсюдження зброї масового знищення. Зокрема, за 2019 рік Держфінмоніторингом підготовлено 893 матеріали (з них 503 узагальнені матеріали та 390 додаткових узагальнених матеріалів), які направлено до:

- органів прокуратури 117 матеріалів (3 них 40 узагальнених матеріалів та 77 додаткових узагальнених матеріалів);

- Державної фіскальної служби України 218 матеріалів (з них 158 узагальнених матеріалів та 60 додаткових узагальнених матеріалів);

- органів внутрішніх справ 173 матеріали (з них - 149 узагальнених матеріалів та 24 додаткових узагальнених матеріалів);

- Служби безпеки України 215 матеріалів (з них - 104 узагальнених матеріали та 111 додаткові узагальнені матеріали);

- Національного антикорупційного бюро України 155 матеріалів (3 них - 41 узагальнений матеріал та 114 додаткових узагальнених матеріалів);

- Державного бюро розслідувань 15 матеріалів (з них - 11 узагальнених матеріалів та 4 додаткові узагальнені матеріали).

У вказаних матеріалах сума фінансових операцій, які можуть бути пов'язані 3 легалізацією коштів та з учиненням іншого 
злочину, визначеного Кримінальним кодексом України, становить 92,2 млрд. гривень.

Так, протягом 2019 року Держфінмоніторингом направлено до правоохоронних органів 211 матеріалів (47 узагальнені матеріали та 164 додаткові узагальнені матеріали), які пов'язані з підозрою у корупційних діяннях, зокрема до: Національного антикорупційного бюро України 155 матеріалів (3 них - 41 узагальнений матеріал та 114 додаткових узагальнених матеріалів); органів прокуратури України 38 матеріалів (3 них - 1 узагальнений матеріал та 37 додаткових узагальнених матеріалів); Служби безпеки України 14 матеріалів (з них - 4 узагальнені матеріали та 10 додаткових узагальнених матеріалів); органів фіскальної служби України 3 матеріали (з них - 1 узагальнений матеріал та 2 додаткові узагальнені матеріали); - органів внутрішніх справ 1 додатковий узагальнений матеріал.

У вказаних матеріалах сума фінансових операцій, які можуть бути пов'язані з легалізацією коштів та $з$ учиненням іншого злочину, визначеного Кримінальним кодексом України, становить 41,8 млрд. гривень [3].

Сутність моніторингу банківських рахунків, відповідно до ст. $269^{1}$ КПК України, полягає в отриманні детективом НАБУ відповідно до ухвали слідчого судді в поточному режимі від банку інформації про операції, що здійснюються на одному або декількох банківських рахунках 3 метою фіксування злочинної дії 3 використанням конкретного банківського рахунку в банківській установі на території України або розшуку чи ідентифікації майна, що підлягає конфіскації або спеціальній конфіскації. Проведення моніторингу банківських рахунків відповідно до статей 246 і $269^{1}$ КПК України можливе лише у кримінальних провадженнях щодо тяжких та особливо тяжких злочинів, віднесених до підслідності НАБУ.

Відповідно до ст. $269^{1}$ КПК України за наявності обгрунтованої підозри, що особа здійснюе злочинні дії з використанням банківського рахунку, або 3 метою роз- шуку чи ідентифікації майна, що підлягає конфіскації або спеціальній конфіскації, у кримінальних провадженнях, віднесених до підслідності НАБУ, прокурор може звернутися до слідчого судді для винесення ухвали про моніторинг банківських рахунків.

Згідно $з$ ухвалою слідчого судді про моніторинг банківських рахунків, банк зобов'язаний надавати НАБУ в поточному режимі інформацію про операції, що здійснюються на одному або декількох банківських рахунках.

Слідчий суддя в ухвалі про моніторинг банківських рахунків повідомляє керівника банківської установи про обов'язок нерозголошення інформації про проведення цієї негласної слідчої (розшукової) дії і про відповідну кримінальну відповідальність. На підставі ухвали слідчого судді керівник банківської установи зобов' язаний письмово попередити усіх їі працівників, залучених до моніторингу банківських рахунків, про обов'язок нерозголошення інформації про проведення цієї негласної слідчої (розшукової) дії і про можливу кримінальну відповідальність.

Інформація про операції, що здійснюються на банківських рахунках, повинна доводитися до відома НАБУ до виконання відповідної операції, а у разі неможливості - негайно після її виконання [4]. Форма та порядок такого повідомлення забезпечує таємний, прихований характер проведення моніторингу банківських рахунків. Рух коштів по банківському рахунку фіксується в протоколі цієї НСРД, який складається відповідно до вимог статей 104-106, 252 КПК України, розділів IV, V Інструкції про організацію проведення негласних слідчих (розшукових)дій та використання результатів у кримінальному провадженні [5].

Проаналізувавши дану НСРД, можемо виокремити їі недоліки процесуальної регламентації: недостатня юридична визначеність процедури провадження; невизначеність процесуальної форми фіксації виявленої доказової інформації; неврегульованість процедури дій посадових осіб, які можуть бути спрямованими на можливість 


\section{Кримінальне право, кримінальний процес та криміналістика}

тимчасової затримки банківських операцій в інтересах слідства, коли повідомлення про оформлювані банківські операції здійснюється до їх виконання.

3 метою більш повного розуміння сутності проблеми моніторингу банківських рахунків розглянемо положення чинного кримінального процесуального законодавства окремих держав: Французької Республіки, Республіки Австрія, Великобританії та Уельсу.

КПК Франції безпосередньо не передбачає моніторинг за банківськими операціями. Однак на практиці це регулюється загальними правилами, передбаченими в КПК, ст. $60^{1}$ КПК Франції, яка, в поєднанні 3 ст. $132^{22}$ Кримінального кодексу, дає право працівникам поліції здійснювати запит на інформацію про банківські рахунки, банківські операції та здійснювати моніторинг. Відповідно до ст. $60^{1}$ КПК Франції, працівник поліції може вимагати у будь-якої особи, установи або організації, незалежно від форми власності, або будьякої державної служби, які можуть володіти будь-якими документами, що мають відношення до справи, надати йому ці документи. Без законних підстав обов'язок зберігати професійну таємницю не може бути причиною невиконання вимоги поліцейського. Ненадання відомостей на вимогу поліцейського в розумний строк становить собою злочин, який карається штрафом. До того ж, відповідно до статті $132^{22}$ Кримінального кодексу Франції прокурор, слідчий суддя або суд може вимагати від сторін, будь-якого органу державної влади, фінансової установи або грошових фондів, не конфіденційного повідомлення відповідної інформації фінансового характеру [6].

КПК Австрії розмежовує відомості про банківські рахунки та банківські операції. У ст. 109 п. 3 КПК Австрії зазначено: «Відомості про банківські операції означають огляд документів і інших записів у кредитній установі або позначають інститут фінансової сфери щодо типу та обсягу ділових відносин, бізнес-операцій і інших дій у сфері бізнесу, а також пов'язані з цим відносини протягом певного періоду часу в минулому або в майбутньому».

Для того, щоб отримувати відомості про банківські операції, необхідна наявність причетності особи до вчинення умисного злочину або іншого злочинного діяння, яка відноситься до компетенції земельного суду. Крім того, ст. 116 п. 2 КПК Австрії вимагає наявності загальної підозри в тому, що відповідно до цієї інформації: окремі документи про ділові відносини можуть бути конфісковані і що ця конфіскація необхідна для розслідування будь-якого злочину; об'єкти або інші активи можуть підлягати конфіскації відповідно до постанов про конфіскацію власності; операція має ознаки злочину, який буде переслідуватися в судовому порядку.

Прокурор, на підставі дозволу суду, повинен ухвалити постанову про моніторинг банківських операцій. Суд у своєму дозволі повинен встановити термін для виконання цієї слідчої дії.

Кредитні та фінансові установи та їх співробітники зобов'язані сприяти огляду документів і записів, а також надавати їх. Установа може оскаржити дозвіл суду i відмовитися надавати інформацію або передати записи. У цьому випадку установа повинна передати відомості та записи органам досудового розслідування в закритому упакуванні. Працівники поліції потім передають ці матеріали Вищому земельному суду, який у подальшому ухвалить рішення про виїмку документів.

Згідно 3 п. 5 ст. 116 КПК Австрії, як тільки відповідна фінансова установа, обвинувачений і особи,які мають розпорядчі повноваження в даних ділових відносинах стають відомими прокурору, постанова прокурора і дозвіл суду повинні бути вручені цим особам. Прокурор може відкласти повідомлення до того моменту, поки це становитиме загрозу досудовому розслідуванню. Відповідно до п. 4 ст. 83 КПК Австрії, якщо обвинувачений стане відомий прокурору перед проведенням слідчої дії i обвинуваченому був наданий захисник, постанова та дозвіл суду мають бути направлені захиснику [7]. 
Закон Великобританії «Про доходи від злочинної діяльності» (The Proceeds of Crime Act) передбачає необхідність видання судом постанови про здійснення моніторингу, за зверненням правоохоронних органів, які розслідують наявність активів, одержаних злочинним шляхом 3 метою їх подальшої конфіскації чи злочини, пов'язані 3 «відмиванням» грошей [8].

Стосовно розслідування справи про подальшу конфіскацію, то повинна бути наявна обгрунтована підозра, що особа, зазначена в постанові, одержує від злочинної поведінки. У разі розслідування справи про відмивання грошей, має бути наявна обгрунтована підозра, що особа, яка зазначена в постанові, вчинила цей злочин.

У всіх випадках повинна бути наявність обгрунтованого переконання вважати, що одержання інформації про банківські рахунки здійснюється в публічних інтересах i ця інформація, ймовірно, становитиме доказову цінність для розслідування справи.

Постанова ухвалюється для того, щоб сприяти розслідуванню справ про конфіскацію або відмивання грошей. Моніторинг банківських рахунків триває до 90 днів, але звертатися з повторним клопотанням можна лише після закінчення цього терміну. Постанова може бути ухвалена тільки стосовно вказаної особи. Для юридичних осіб не встановлено ніяких спеціальних правил. Банк або фінансова установа зобов'язані виконувати постанову, і таким чином здійснюють співпрацю з органами досудового розслідування.

Дозвіл надається або Судом Корони (Crown Court) або Верховним судом, в залежності від характеру розслідування. Постанова видається в письмовій формі [8].

\section{Висновки}

Внесення змін до чинного кримінального процесуального законодавства, зокрема доповнення такою негласною слідчою (розшуковою) дією, як «Моніторинг банківських рахунків», породжує чимало проблем і запитань, що потребують подальшого врегулювання 3 точки зору науковців й практиків. Варто усвідомлюва- ти, що така діяльність може передбачати й очевидні зловживання, мати замовне забарвлення. Як і будь-яка негласна слідча (розшукова) дія, моніторинг банківських рахунків має детально регламентуватися 3 дотриманням принципів юридичної визначеності та пропорційності. Кримінальне процесуальне законодавство України повинно враховувати, що мета застосування такої дії має бути суспільно значущою, а засіб для її досягнення - найменш обтяжливим під час провадження. Перспективи подальшого дослідження проблеми вбачаються в розробці пропозицій щодо удосконалення ст. $269^{1}$, запозиченні світового досвіду, дотриманні міжнародно-правових стандартів тощо.

\section{Література}

1. Про запобігання та протидію легалізації (відмиванню) доходів, одержаних злочинним шляхом, фінансуванню тероризму та фінансуванню розповсюдження зброї масового знищення: Закон України від 28.04.2020 р. № 361-XI URL: https:// zakon.rada.gov.ua/laws/show/361-IX (дата звернення 20.05.2020).

2. Рекомендації FATF: Міжнародні стандарти з протидії відмиванню доходів та фінансуванню тероризму i розповсюдженню зброї масового знищення. URL: https://www.sdfm.gov.ua/assets/userfiles/ books/5\%20round\%20FATF.pdf (дата звернення 23.05.2020).

3 . Інформування про результати роботи Держфінмоніторингу за 2019 рік URL: https://fiu.gov.ua/pages/dijalnist/fukcional/ news/Informuvannya-pro-rezultati-robotiderzhfinmonitoringu-za-2019-rik.html (дата звернення 23.05.2020).

4. Кримінальний процесуальний кодекс України: Закон України від 16.04.2013. №4651-VI. URL: https://zakon. rada.gov.ua/laws/show/4651-17/paran2436 (дата звернення 23.05.2020).

5. Хавронюк М.I. Настільна книга детектива, прокурора, судді: коментар антикорупційного законодавства. К. : ВД «Дакор», 2016. С. 458.

6. Criminal procedure code of France. URL: https://www.legislationline.org/ 


\section{Кримінальне право, кримінальний процес та криміналістика}

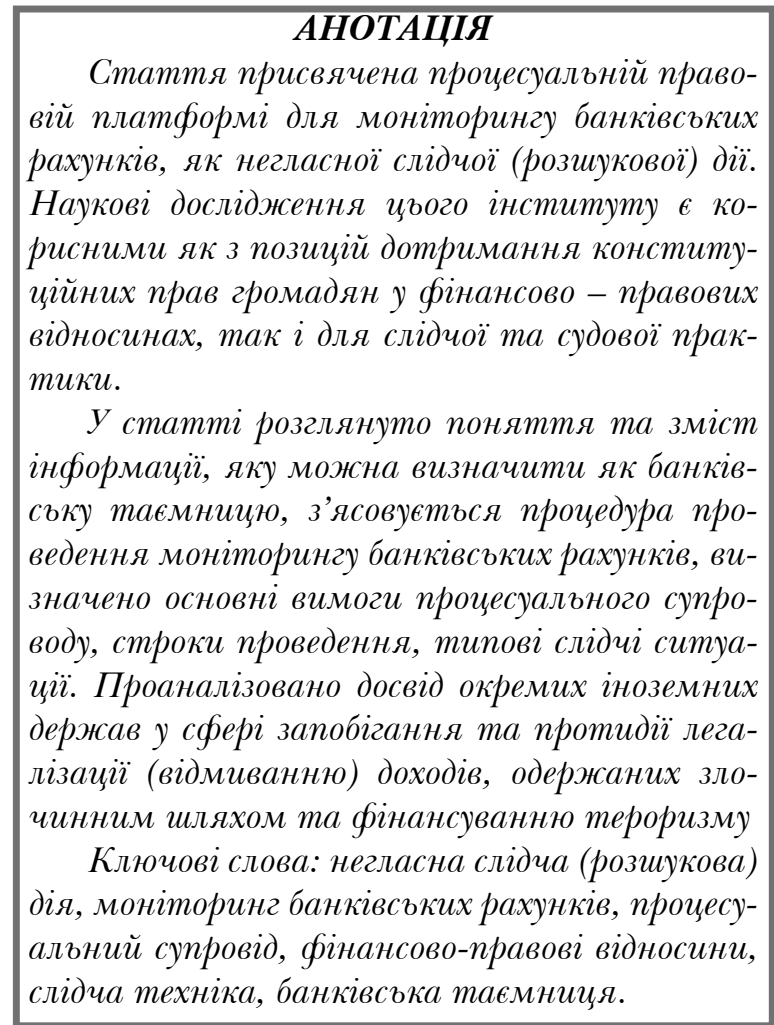

download/id/6381/file/France_CPC_am2006_ en.pdf (дата звернення 23.05.2020).

7. Strafprozessordnung

(StPO)

Österreich. URL: https://www.jusline.at/ gesetz/stpo (дата звернення 23.05.2020).

8. The Proceeds of Crime Act 2002. URL: http://www.legislation.gov.uk/ukpga/2002/29/ contents (дата звернення 23.05.2020).
For most European countries, the means, which are similar to the native investigative actions in the course of the criminal case, have become usual. According to the official data in some European countries (such as Great Britain, Germany, France, The Netherlands, Denmark, Switzerland, etc.) at the end of $80 \mathrm{~s}-$ the beginning of the 90s of the XIX century the Criminal Law were foreseen new, as they were called "special" investigative actions.

Monitoring of the bank accounts as unspoken investigative action was implemented in our law in order to provide for the international obligations of Ukraine in the fight with money laundry and terrorism financial support, and also for giving the National Anticorruption Bureau of Ukraine the opportunity to effectively fight with the corruption of the high level authorities.

The intergovernmental authority that develops and implements actions and standards on the international level as for the money laundry is Financial Action Task Force on Money Laundering (FATFML). This authority actively cooperates with many international organizations, which are targeting to combat "dirty" money laundry.

Financial Action Task Force on Money Laundering recommends that the countries should provide the appropriate authorities on site have the capability of taking a wide spectrum of investigational actions in the money laundry investigations, connected crimes and financing the terrorism. These are the following investigational techniques: secret operations, connection interception, access to the computer systems and controlled supplies.

In Ukraine such authority is the State Financial Monitoring Service. This Service, as a financial intelligence of Ukraine, takes the intensified measures of the practical nature when fighting the incomes laun$d r y$, which were gained in a criminal way, terrorism financing and financing of the mass destruction weapon spreading.

Bank accounts monitoring means that according to the Criminal Code of Ukraine, the National Anticorruption Bureau of Ukraine's detective by the decision of the investigating judge gains the current information from bank as for the transactions on one or many accounts in order to place the criminal actions with the help of a particular bank account in the bank on the territory of Ukraine; or to look for or identify the property which is to be confiscated. According to the Criminal Code of Ukraine bank accounts monitoring is only possible during the criminal investigations of the felony or extremely serious crime, which are under the National Anticorruption Bureau of Ukraine jurisdiction.

Key words: covert investigative (search) action, monitoring of bank accounts, procedural support, financial and legal relations, investigative equipment, banking secrecy. 